Original article

\title{
Selective cytotoxic and genotoxic activities of 5-(2-bromo-5- methoxybenzylidene)-thiazolidine-2,4-dione against NCI-H292 human lung carcinoma cells
}

\author{
Maria do D. Rodrigues ${ }^{\mathrm{a}}$, Priscila B.G.S. Santiago ${ }^{\text {a }}$, Karla M.R. Marques ${ }^{\mathrm{a}}$, \\ Valéria R.A. Pereira ${ }^{b}$, Maria C.A.B. de Castro $^{\text {b,c }}$, Jeanne C.L.L. Cantalice ${ }^{a}$, \\ Teresinha G. da Silva ${ }^{a}$, Mônica L. Adam ${ }^{\mathrm{d}}$, Silene C. do Nascimento ${ }^{\mathrm{a}}$, \\ Julianna F.C. de Albuquerque ${ }^{\mathrm{a}}$, Gardenia C.G. Militao ${ }^{\mathrm{e}, *}$ \\ a Department of Antibiotics, Federal University of Pernambuco, Recife, PE, Brazil \\ ${ }^{\mathrm{b}}$ Department of Immunology, Oswaldo Cruz Foundation, Aggeu Magalhães Research Center, Campus da UFPE, Recife, PE, Brazil \\ ${ }^{\mathrm{c}}$ Academic Center of Vitoria, Federal University of Pernambuco, Parasitology Laboratory, Recife, PE, Brazil \\ ${ }^{\mathrm{d}}$ Department of Biological Sciences, Academic Center of Victoria, Federal University of Pernambuco, Receife, PE, Brazil \\ e Department of Physiology and Pharmacology, Federal University of Pernambuco, Recife, PE, Brazil
}

\section{A R T I C L E I N F O}

\section{Article history:}

Received 26 January 2017

Received in revised form 29 September 2017

Accepted 20 November 2017

Available online 22 November 2017

\section{Keywords:}

Cytotoxicity

Genotoxicity

5-Benzylidene-2,4-thiazolidinedione

Lung cancer
A B S T R A C T
Background: Thiazolidine-2,4-dione ring system is used as a pharmacophore to build various heterocyclic
compounds aimed to interact with biological targets. In the present study, benzylidene-2,4-
thiazolidinedione derivatives (compounds $\mathbf{2 - 5}$ ) were synthesized and screened against cancer cell
lines and the genotoxicity and cytotoxicity of the most active compound (5) was investigated on normal
and lung cancer cell line.
Methods: For in vitro cytotoxic screening, the MTT assay was used for HL60 and K562 (leukemia), MCF-7
(breast adenocarcinoma), HT29 (colon adenocarcinoma), HEp-2 (cervix carcinoma) and NCI-H292 (lung
carcinoma) tumor cell lines and Alamar-blue assay was used for non-tumor cells (PBMC, human
peripheral blood mononuclear cells) were used. Cell morphology was visualized after Giemsa-May-
Grunwald staining. DNA content, phosphatidylserine externalization and mitochondrial depolarization
were measured by flow cytometry. Genotoxicity was assessed by Comet assay.
Results: 5-(2-Bromo-5-methoxybenzylidene)-thiazolidine-2,4-dione (5) presented the most potent
cytotoxicity, especially against NCI-H292 lung cancer cell line, with IC 50 value of $1.26 \mu$ g/mL after $72 \mathrm{~h}$
incubation. None of the compounds were cytotoxic to PBMC. After $48 \mathrm{~h}$ incubation, externalization of
phosphatidylserine, mitochondrial depolarization, internucleosomal DNA fragmentation and morpho-
logical alterations consistent with apoptosis were observed in NCI-H292 cells treated with compound (5).
In addition, compound (5) also induced genotoxicity in NCI-H292 cells ( 2.8 -fold increase in damage index
compared to the negative control), but not in PBMC.
Conclusion: Compound $\mathbf{5}$ presented selective cytotoxic and genotoxic activity against pulmonary
carcinoma (NCI-H292 cells).
(c) 2017 Institute of Pharmacology, Polish Academy of Sciences. Published by Elsevier Sp. z o.o. All rights reserved.

\section{Introduction}

Cancer is one of the leading causes of mortality worldwide characterized by sustained chronic proliferation of immortal cells,

\footnotetext{
* Corresponding author.

E-mail address: gcgadelha@yahoo.com.br (G.C.G. Militao).
}

evasion of growth suppressors' programs, resistance to cell death, development of angiogenesis, tissue invasion and metastasis [1]. The most common sites of cancers diagnosed among men are lung, prostate, colorectal, stomach and liver. Meanwhile, most common sites of cancer in women are breast, colorectal, lung, cervix and stomach. The total number of cancer related deaths worldwide raised from 8.2 million in 2012 to 8.8 million in 2015 and lung cancers caused approximately 1.69 million deaths in 2015 [2-4]. 


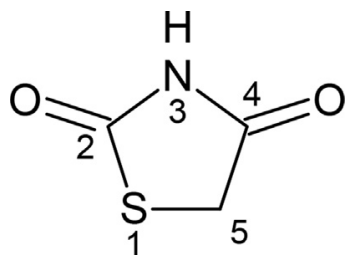

Fig. 1. Thiazolidine-2,4-dione ring.

Thiazolidine-2,4-dione ring (Fig. 1) system exhibits a broad spectrum of biological activities, such as hypoglycemic [5,6], antimycobacterial [7], anti-inflammatory [8], antileishmanial [9], antibiotics [7,10] and antitumor [11]. Much attention has been given to the construction of new derivatives of thiazolidinediones with anticancer activity [12-14].

Heterocyclic molecules belonging to the thiazolidinedione class represents a new alternative in the search for drugs with antineoplastic potential. Thiazolidinediones exhibit antitumor effects through both PPAR $\gamma$-dependent and -independent mechanisms [15,16]. The role of PPAR $\gamma$ (peroxisome proliferatoractivated receptors) in tumor cells has been extensively investigated and treatment with PPAR $\gamma$ agonists exert biological effects such as cell growth control, motility, differentiation and apoptosis $[16,17]$ PPAR $\gamma$-independent mechanism of tumor cell death induced by thiazolidinediones treatments includes proteasomedependent degradation of cyclins (D1 and D3) with consequent cell cycle blockage at $\mathrm{G}_{1}-\mathrm{S}$ transition, induction of cellular acidosis through inhibition of the $\mathrm{Na}^{+} / \mathrm{H}^{+}$exchanger and release of apoptotic factors from the mitochondria due to the production of reactive oxygen species (ROS) [15].

Among many thiazolidinediones derivatives with distinct biological activities, 5-benzylidene-2,4-thiazolidinedione and its analogues presented cytotoxic activity against a variety of different cell lines: compound 2-[4-[(2,4-Dioxothiazolidin-5-ylidene) methyl] phenoxy]- $N$-[3-(trifluromethyl) phenyl] acetamide was active against K562 leukemia, MCF-7 (breast cancer), PC3 (Prostate cancer), KB (Nasopharyngeal cancer) and GURAV (Oral cancer) [18]; 5-(4-(2-(piperidin-1-yl)ethoxy)benzylidene)thiazolidine2,4-dione was active against a panel of 60 human tumor cell [19]. In fact, a wide variety of substituents in the thiazolidine-2,4dione (TZD) nucleus lead to a huge diversity of compounds targeting different signaling pathways related to cell proliferation or cell death [11].

One of the most important characteristic for a new molecule with action against cancer is its selectivity toward tumor cells, since many anticancer drugs cause diverse cytotoxic and genotoxic damages also in normal cells. Although there are many reports indicating a wide range of biological activities for compounds with a thiazolidine-2,4-dione nucleus, genotoxicity studies in normal cells are still insufficient. In this context, this study aimed to evaluate in vitro antitumor effects of 5-benzylidene-2,4thiazolidinedione derivatives, as well as to investigate the possible mechanisms of action, and genotoxic outcomes of these compounds on human normal and tumor cells.

\section{Materials and methods}

\section{Synthesis of thiazolidine-2,4-dione derivatives compounds}

The synthesis methodology of compounds 1 to 5 was already described [9]. Briefly, the thiazolidine-2,4-dione (1) was obtained by the method already described $[20,21]$. This reaction occurs by condensation of monochloroacetic acid and thiourea in an aqueous medium under reflux for $24 \mathrm{~h}$. The series of thiazolidine-2,4-dione derivatives were originated by changes in the 5 position of the heterocyclic ring (Fig. 1). The compounds5-(2-bromo-6-fluorobenzylidene)-thiazolidine-2,4-dione (2), 5-(2-Hydroxy-3-bromo5-chlorobenzylidene)-thiazolidine-2,4-dione (3), 5-(2-Hydroxy-5clorobenzylidene)-thiazolidine-2,4-dione (4) e 5-(2-bromo-5methoxybenzylidene)-thiazolidine-2,4-dione (5) were synthesized according to protocol described previously [9] (Fig. 2). A solution of thiazolidine-2,4-dione $\left(0.2 \mathrm{~g}, 1.70 \times 10^{-3} \mathrm{~mol}\right)$ in ethanol, ( $7.0 \mathrm{ml})$ containing piperidine (2 drops) and aromatic aldehyde $\left(0.184 \mathrm{~g}, 2.25 \times 10^{-3} \mathrm{~mol}\right)$ was heated $\left(70^{\circ} \mathrm{C}\right)$, under stirring, for 5-9 h. Afterward, the product was cooled in an ice bath, filtered and recrystallized with an appropriate solvent. The resulting precipitate was filtered off and recrystallized from acetic acid to give the compounds (2-5). All compounds were identified by IR spectroscopy method, NMR and HRMS (Supplementary material). The yields obtained ranged from 73 to $79 \%$.

\section{Cell lines}

The cell lines NCI-H292 (Mucoepidermoid pulmonary carcinoma), HL60 (Promyelocytic leukemia), HT-29 (Colon adenocarcinoma), K562 (Chronic myelogenous leukemia), HEp-2 (cervix carcinoma) and MCF-7 (Breast adenocarcinoma) were obtained from The Rio de Janeiro cell bank, Brazil. The cells were maintained in DMEM or RPMI 1640 medium. All cell lines were supplemented with $10 \%$ fetal bovine serum (GIBCO), $1 \%$ antibiotic solution (penicillin 5000 Units $/ \mathrm{mL}+$ streptomycin $5000 \mu \mathrm{g} / \mathrm{mL}$ ) and $1 \%$ L-glutamine $200 \mathrm{mM}$.<smiles>[R]C=C1SC(=O)NC1=O</smiles>

Fig. 2. Synthetic routes and structure of compounds 2-5. 
Cytotoxic activity in tumor cells

The 3-(4,5-dimethyl-2-thiazolyl)-2,5-diphenyl-2H-tetrazolium bromide (MTT) (Sigma Aldrich Co., St. Louis, MO, USA) reduction assay was used for cytotoxicity. Tumor cells were plated in 96-well plates $\left(10^{5}\right.$ cells $/ \mathrm{mL}$ for adherent cells or $3 \times 10^{5}$ cells $/ \mathrm{mL}$ for leukemia). Tested compounds $(0.39-25 \mu \mathrm{g} / \mathrm{mL})$ dissolved in DMEM with DMSO $0.007 \%$ for the lowest concentration $(0.39 \mu \mathrm{g} / \mathrm{mL})$ to $0.5 \%$ for the highest concentration $(25 \mu \mathrm{g} / \mathrm{mL})$ of compounds were added to each well. Subsequently, cells were incubated for $72 \mathrm{~h}$. The compound $\mathbf{5}$ was also evaluated after 24 and $48 \mathrm{~h}$ of incubation in NCI-H292 cells. Control groups received the same amount of DMSO. After $69 \mathrm{~h}$ of treatment $25 \mu \mathrm{L}$ of MTT $(5 \mathrm{mg} / \mathrm{mL})$ was added, three hours later the supernatant was removed and the MTT-formazan product was dissolved in $100 \mu \mathrm{L}$ of DMSO, and absorbance was measured at $570 \mathrm{~nm}$ in plate spectrophotometer. Doxorubicin $(0.01-5 \mu \mathrm{g} / \mathrm{mL})$ was used as positive control. Data are presented as $\mathrm{IC}_{50}$ (concentration that cause $50 \%$ of cell growth inhibition) values with their $95 \%$ confidence intervals (CI 95\%) obtained by non linear regression after normalize the absorbance results against untreated control samples [22].

Peripheral blood mononuclear cells isolation and cytotoxic activity (PBMC)

Mononuclear cells (lymphocytes and monocytes) were obtained from the peripheral blood of healthy volunteers collected in sterile tubes with heparin solution (BD Vacutainer ${ }^{\mathrm{TM}}$ ) as an anticoagulant. The protocol was approved by The Human Research Ethics Committee ( ${ }^{\circ}$ CAAE 48809515700005208). The total blood $(6 \mathrm{~mL})$ was diluted in $3 \mathrm{~mL}$ PBS and layered onto $2 \mathrm{~mL}$ Ficoll ${ }^{\mathbb{R}}$ Hystopaque (Sigma). For phase separation of the solution, the tube was centrifugated at $1500 \mathrm{rpm}$ for $30 \mathrm{~min}$. After centrifugation the mononuclear cells were concentrated in the middle layer located between the plasma (light phase) and erythrocytes (dark phase). Afterwards the PBMC were transferred to another tube with PBS to a final volume of $11 \mathrm{~mL}$. The cells were pelleted by centrifugation and resuspended in RPMI 1640 medium supplemented with 20\% fetal bovine serum and $1 \%$ antibiotics $1 \%$ antibiotic solution (penicillin 5000 Units $/ \mathrm{mL}+$ streptomycin $5000 \mu \mathrm{g} / \mathrm{mL}$ ). Phytohemagglutinin $2 \%$ (Sigma) was added to the medium to stimulate the proliferation of lymphocytes. Cells were seeded at $10^{6}$ cells $/ \mathrm{mL}$ in 96 well plates. After $24 \mathrm{~h}$ of incubation, compounds were dissolved in DMEM with DMSO and added to each well. Doxorubicin $(0.078-10 \mu \mathrm{M})$ was used as a positive control. The negative control received the same amount of DMSO. Twenty-four hours before the end of the incubation period (total time of $72 \mathrm{~h}$ ), $10 \mu \mathrm{L}$ of Alamar Blue stock solution $(0.312 \mathrm{mg} / \mathrm{mL})$ was added to each well. The absorbances were measured at $570 \mathrm{~nm}$ (oxidized state) and $595 \mathrm{~nm}$ (reduced state) in a plate spectrophotometer. Cell proliferation that was calculated by the following formula: \% proliferating $=\mathrm{ALW}-(\mathrm{AHW} \times \mathrm{R} 0) \times 100$, where ALW is the absorbance at the lowest wavelength $(570 \mathrm{~nm})$ e AHW is the absorbance at highest wavelength $(595 \mathrm{~nm})$, respectively. The R0 was calculated according to the formula: $\mathrm{RO}=$ (absorbance of medium with Alamar Blue minus absorbance of medium without Alamar blue at $570 \mathrm{~nm}$ )/(absorbance of medium with Alamar Blue minus absorbance of medium without Alamar blue at $595 \mathrm{~nm}$ ) [23].

Evaluation of hemolytic potential in human erythrocytes

Blood was collected from healthy volunteers. Erythrocytes were pelleted by centrifugation ( $3000 \mathrm{rpm} / 5 \mathrm{~min}$ ) and resuspended in saline $(0.85 \% \mathrm{NaCl}+10 \mathrm{mM} \mathrm{CaCl} 2)$ to obtain $2 \%$ erythrocytes solution (SE) $2 \%$. The 96 -well plates were prepared according to the following: $100 \mu \mathrm{L}$ of saline (negative control); $50 \mu \mathrm{L}$ of saline solution and $50 \mu \mathrm{L}$ of vehicle with $1 \%$ DMSO (Blank); $80 \mu \mathrm{L}$ saline $+20 \mu \mathrm{L}$ Triton $\mathrm{X}-1001 \%$ (positive control); $50 \mu \mathrm{L}$ of saline solution and $50 \mu \mathrm{L}$ of compounds $(1.95-250 \mu \mathrm{g} / \mathrm{mL}$ ) diluted in $1 \%$ DMSO. Then $100 \mu \mathrm{L}$ of the solution of erythrocytes was plated in each well. After incubation for $1 \mathrm{~h}$ under constant agitation at room temperature, the supernatant was analyzed in automatic plate reader $(450 \mathrm{~nm})$. The $50 \%$ effective concentration $\left(\mathrm{EC}_{50}\right)$ and their $95 \%$ confidence intervals were determined from nonlinear regression.

Morphological changes induced compound 5 (5-(2-bromo-5methoxybenzylidene)-thiazolidine-2,4-dione) on lung adenocarcinoma (NCI-H292)

Compound 5, the most active compound, was selected for further investigation of cytotoxicity on lung carcinoma NCI-H292. Cells cells $\left(10^{5}\right.$ cells $/ \mathrm{mL}$ ) were treated for $48 \mathrm{~h}$ with Compound 5 at 8.0 and $16.0 \mu \mathrm{g} / \mathrm{mL}$, the $\mathrm{IC}_{50}$ and $2 \times \mathrm{IC}_{50}$ for $48 \mathrm{~h}$, respectively. Afterward, slides were prepared by cytospin centrifugation. To evaluate the morphology, the cells were fixed with methanol for $1 \mathrm{~min}$ and stained with May-Grunwald-Giemsa. Doxorubicin $(0.5 \mu \mathrm{g} / \mathrm{mL})$ was used as a positive control.

\section{Analysis by flow cytometry}

\section{Externalization of phosphatidylserine in NCI-H292 after treatment} with compound 5

The externalization of phosphatidylserine was evaluated by annexin/propidium iodite staining. NCI-H292 cells were treated with compound 5 at 8 and $16 \mu \mathrm{g} / \mathrm{mL}$ for $48 \mathrm{~h}$, the $\mathrm{IC}_{50}$ and $2 \times \mathrm{IC}_{50}$ for $48 \mathrm{~h}$, respectively. Doxorubicin $(0.5 \mu \mathrm{g} / \mathrm{mL})$ was used as positive control. Cells were harvested and incubated with AnnexinFitV-FITC kit according to the manufacturer (Sigma). Cell fluorescence was then determined by flow cytometry on a BD cytometry - FACS Calibur - CBA. Twenty thousand events per experiment were acquired and cell debris were omitted from the analysis. The percentages of viable cells, early apoptotic, late apoptotic and necrotic cells were graphed using Prism 5.0 (GraphPad Software Inc.).

Measurement of mitochondria transmembrane potential in NCI-H292 after treatment with compound $\mathbf{5}$

$\mathrm{NCI}-\mathrm{H} 292$ cells treated with compound 5 at 8 and $16 \mu \mathrm{g} / \mathrm{mL}$ for $48 \mathrm{~h}$, the $\mathrm{IC}_{50}$ and $2 \times \mathrm{IC}_{50}$ for $48 \mathrm{~h}$, respectively and doxorubicin $(0.5 \mu \mathrm{g} / \mathrm{mL})$ were centrifuged at $2000 \mathrm{rpm}$ for $5 \mathrm{~min}$, washed with PBS and stained with $200 \mu \mathrm{L}$ of rhodamine $123(1 \mu \mathrm{g} / \mathrm{mL})$ for $15 \mathrm{~min}$. Subsequently, cells were pelleted again and incubated with PBS for $30 \mathrm{~min}$. Cell fluorescence was then determined by flow cytometry. Twenty thousand events per experiment were acquired and cell debris were omitted from the analysis [24].

DNA content of NCI-H292 cells (DNA fragmentation and cell cycle) after treatment with compound $\mathbf{5}$

Cells were collected, pelleted and fixed with cold ethanol (70\%) for $1 \mathrm{~h}$. After washing with phosphate buffer saline to remove ethanol, treated and untreated cells were incubated with $100 \mu \mathrm{L}$ of lysis solution $(0.1 \%$ sodium citrate, $0.1 \%$ triton $X-100$ and $2 \mu \mathrm{g} / \mathrm{mL}$ of propidium iodide). After $30 \mathrm{~min}$ cell fluorescence of the samples were analyzed on a BD cytometry - FACS Calibur - CBA. FlowJo was used to calculate the cell cycle parameters, based on the cells PI emission (analyzed in the FACSCalibur FL2 channel that captures 564-606 nm emissions). Twenty thousand events per experiment were acquired and cell debris were omitted from the analysis [25]. 

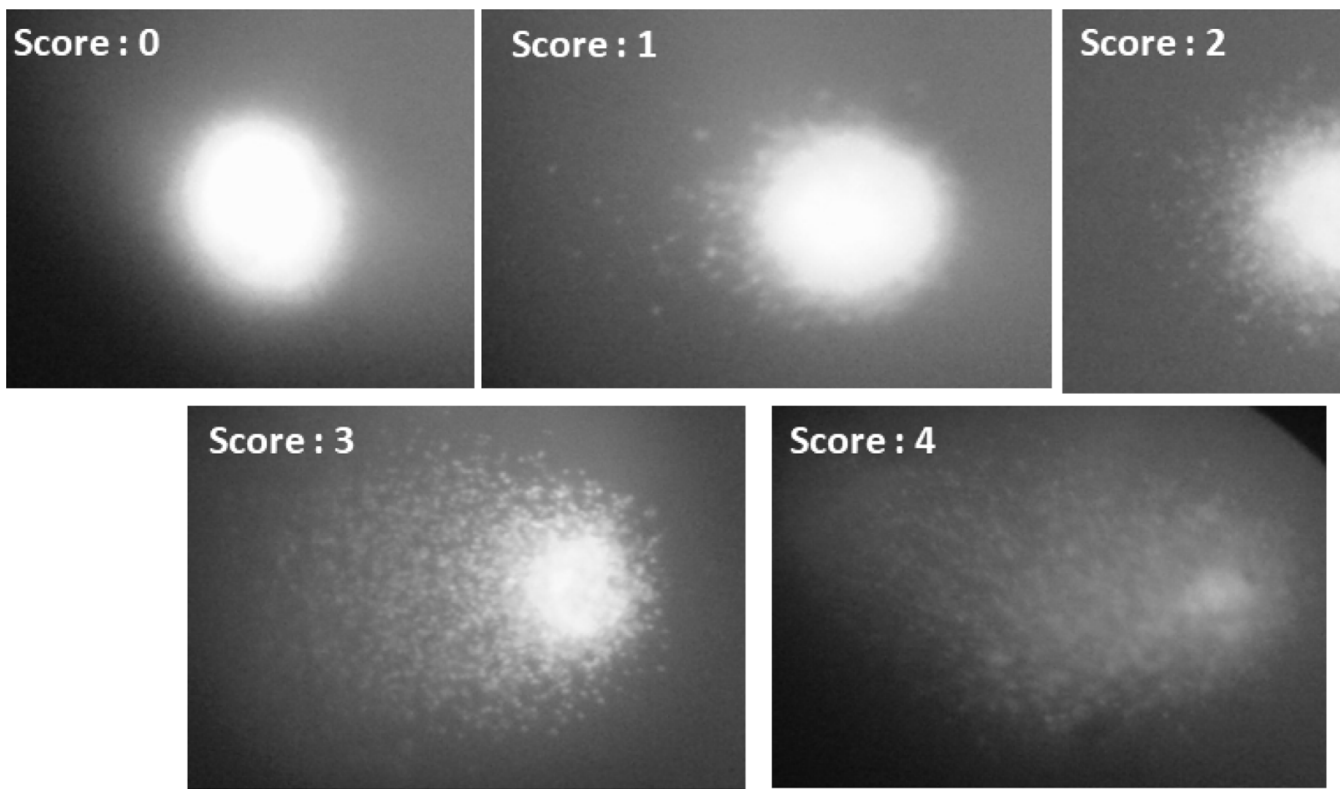

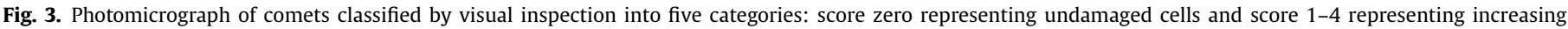
damage. $1000 \times$ magnification.

\section{Genotoxic effect of compound 5 in tumor and normal cell lines - comet assay}

We evaluated the genotoxic effect of compound $\mathbf{5}$ using the comet assay [26]. Approximately $2 \times 10^{5}$ cells/mL of the NCIH-292 were treated with compound 5 for $48 \mathrm{~h}$. To investigate the initial effects on DNA damage induced by compound 5 we used the $72 \mathrm{~h}$ $\mathrm{IC}_{50}$ and $2 \times \mathrm{IC}_{50}, 1.26$ and $2.5 \mu \mathrm{g} / \mathrm{mL}$, respectively. For normal cells, we choose $2 \times \mathrm{IC}_{50}$ and $4 \times \mathrm{IC}_{50}$ found in cancer cells. PBMC were treated with compound 5 with 2.5 and $5.0 \mu \mathrm{g} / \mathrm{mL}$ for $48 \mathrm{~h}$. Doxorubicin $(0.5 \mu \mathrm{g} / \mathrm{mL})$ was used as a positive control. The negative control received the same amount of DMSO as treated samples (0.5\%). After treatment, cells were harvested and $15 \mu \mathrm{L}$ of the cell suspension was embedded in low melting point agarose at $37^{\circ} \mathrm{C}$. The homogenate was then casted on agarose-coated glass slide. Slides were stored in the dark at $4{ }^{\circ} \mathrm{C}$ for $20 \mathrm{~min}$ before adding electrophoresis buffer. Gel electrophoresis was performed at $40 \mathrm{~V}$ for $20 \mathrm{~min}$ and $300 \mathrm{~mA}$. The slides were neutralized in $0.2 \mathrm{M}$ Tris buffer ( $\mathrm{pH} 7.5$ ) for $15 \mathrm{~min}$ and fixed with $98 \%$ ethanol for $5 \mathrm{~min}$. After drying, the slides were stored in a refrigerator until staining. Staining was performed through 1:1000 Gel Red (BiotargetGelRed $\left.{ }^{\circledR}\right)$ addition onto each slide. We analyzed the slides using a fluorescence microscope (Olympus - BX series). Approximately 100 cells per treatment were analyzed and scored from 0 to 4 points depending on the degree of damage in the nucleoid as the following criteria: (a) class 0: undamaged, with no tail; (b) class 1 : with tail shorter than the diameter of the head (nucleus); (c) class 2: with tail length between one and two times the diameter of the head; (d) class 3: with tail longer than two times the diameter of the head; and (e) class 4: comets with no heads. The damage index (DI) can vary from $0(0 \times 100)$ to $400(4 \times 100)$ [27]. Examples of comets from our experiment are provided for better understanding of the classification used (Fig. 3).

\section{Statistical analysis}

For cytotoxicity assays, $\mathrm{IC}_{50}$ values and their $95 \%$ confidence intervals were obtained by non-linear regression. In order to determine the differences, the data were compared by analysis of variance (ANOVA) followed by Dunnett's test $(p<0.05)$. The GraphPad Prism version 5.00 was used for statistical analysis.

\section{Results}

Cytotoxic activity of thiazolidine-2,4-dione derivatives in tumor cells

Four compounds were tested in six human tumor cell lines HEp-2, HT-29, HL-60, MCF-7, K562, and NCI-H 292 and cytotoxicity was determined by MTT assay after $72 \mathrm{~h}$ of incubation. Compounds 2, 3 and $\mathbf{4}$ showed low cytotoxic activity with $\mathrm{IC}_{50}$ values ranging from $9.0 \mu \mathrm{g} / \mathrm{mL}$ to $25.0 \mu \mathrm{g} / \mathrm{mL}$ (Table 1 ). Compound $\mathbf{5}$ was the most active compound with lowest $\mathrm{IC}_{50}$ value $(1.2 \mu \mathrm{g} / \mathrm{mL})$ for lung cancer (NCI-H292). All cell lines were inhibited by the positive control doxorubicin, being HEp-2 and HT-29 the most resistant cell lines. In order to investigate the time

Table 1

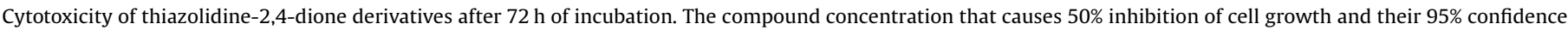
interval (CI95\%) are expressed in $\mu \mathrm{g} / \mathrm{mL}$. Doxorubicin was used as positive control (DOX).

\begin{tabular}{|c|c|c|c|c|c|c|}
\hline \multirow[b]{2}{*}{ Compound } & \multicolumn{6}{|c|}{ Tumor cell line $\mathrm{IC}_{50}(\mathrm{CI} 95 \%) \mu \mathrm{g} / \mathrm{mL}$} \\
\hline & HEp-2 & HL-60 & HT-29 & $\mathrm{K}-562$ & MCF-7 & $\mathrm{NCI}-\mathrm{H} 292$ \\
\hline 2 & $>25$ & $9.0(6.8-11.9)$ & $>25$ & $>25$ & $20.2(16.4-24.7)$ & $15.4(12.9-18.4)$ \\
\hline 3 & $>25$ & $16.1(13.9-18.9)$ & $>25$ & $11.6(8.7-15.4)$ & $17.9(15.6-20.6)$ & $10.9(8.8-13.5)$ \\
\hline 4 & $>25$ & $10.2(7.7-13.3)$ & $>25$ & $17.0(8.2-35.1)$ & $>25$ & $16.9(12.8-22.4)$ \\
\hline 5 & $>25$ & $2.0(1.5-2.7)$ & $>25$ & $6.8(0.2-14.5)$ & $3.5(1.8-6.3)$ & $1.26(0.9-1.7)$ \\
\hline DOX & $1.2(0.5-2.4)$ & $0.03(0.02-0.03)$ & $0.7(0.3-1.0)$ & $0.24(0.16-0.39)$ & $0.5(0.36-0.74)$ & $0.3(0.17-0.9)$ \\
\hline
\end{tabular}

$\mathrm{IC}_{50}$ : Concentration that causes $50 \%$ inhibition of cell growth, and (CI95\%) confidence interval. Dox: doxorubicin. 


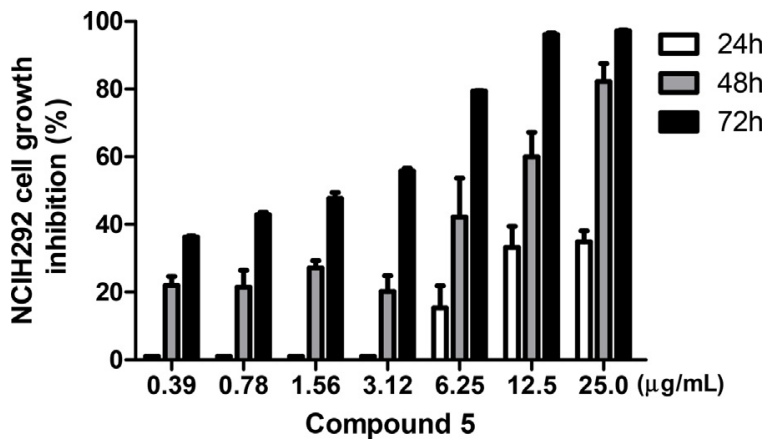

Fig. 4. Time-dependent growth inhibition effect of compound 5 in $\mathrm{NCI}-\mathrm{H} 292$ cell line. Tumor cells were treated with 7 different concentrations at 24,48 and $72 \mathrm{~h}$.

dependency of compound 5 cytotoxic activity, NCI-H292 cells were treated for $24 \mathrm{~h}$ and $48 \mathrm{~h}$. Compound 5 presented $\mathrm{IC}_{50}$ $>25 \mu \mathrm{g} / \mathrm{mL}$ after $24 \mathrm{~h}$ of treatment and $\mathrm{IC}_{50}$ of $7.9 \mu \mathrm{g} / \mathrm{mL}$ after $48 \mathrm{~h}$ of treatment (Fig. 4).

Cytotoxic activity of thiazolidine-2,4-dione derivatives on peripheral blood mononuclear cells (PBMC) and hemolytic activity

Compounds that cause non-specific cell death targeting the cell plasmatic membrane are very toxic. A positive hemolytic assay excludes the compound from being used as therapeutic drug. None of the compounds tested were toxic to human erythrocytes $\left(\mathrm{EC}_{50}\right.$ $>125 \mu \mathrm{g} / \mathrm{mL}$ ). In addition, the compounds were tested in a model of human normal cells: peripheral blood mononuclear cells. After isolation from human blood, PBMC cultivated under mitogenic stimulus works as a model of normal cells. Compounds $\mathbf{2}$ to $\mathbf{5}$ were not cytotoxic to PBMC after $72 \mathrm{~h}$ of treatment ( $\mathrm{IC}_{50}>25 \mu \mathrm{g} / \mathrm{mL}$ ).
The results indicated that the compound $\mathbf{5}$ showed selectivity for tumor cell lines since it causes tumor cell growth inhibition but it does not cause hemolysis of human erythrocytes neither cytotoxicity toward PBMC.

\section{Analysis of cell morphology - May - Grünwald - Giemsa staining}

The cell morphology was analyzed by optical microscopy after $48 \mathrm{~h}$ of incubation. NCI-H292 untreated cells (negative control $\mathrm{CN}$ ) showed typical cellular morphology of adherent cells with intact nuclear and plasmatic membrane and the presence of mitotic cells (Fig. 5). Cells treated with compound 5 at $8.0 \mu \mathrm{g} / \mathrm{mL}$ and $16.0 \mu \mathrm{g} / \mathrm{mL}$ exhibit morphological changes consistent with apoptosis including the cell volume reduction and nuclear fragmentation (Fig. 5). Doxorubicin $(0.5 \mu \mathrm{g} / \mathrm{mL})$ reduced the number of cells, induced reduction of cell volume, chromatin condensation and nuclear fragmentation in NCI- H292 cells.

\section{Phosphatidylserine externalization analysis and mitochondrial transmembrane potential by flow citometry}

The percentage of $\mathrm{NCI}-\mathrm{H} 292$ apoptotic cells was significantly higher $(p<0.05)$ after $48 \mathrm{~h}$ treatment with compound 5 at $16 \mu \mathrm{g} / \mathrm{mL}$ (64\%) compared to the negative control (15\%). Doxorubicin $0.5 \mu \mathrm{g} / \mathrm{mL}$ also induced apoptosis (51\%) compared to the negative control $(p<0.05)$. None of the treatments induced increase on necrotic cells (Figs. 6 and 7). The mitochondrial membrane potential evaluation was performed by flow cytometry. Rhodamine 123, a green-fluorescent dye, is sequestered by active mitochondria. When mitochondria depolarizes due to membrane damage, the dye is lost and the average fluorescence decrease. After exposure of NCI-H292 to compound $5(16.0 \mu \mathrm{g} / \mathrm{mL})$ for $48 \mathrm{~h} \mathrm{a}$
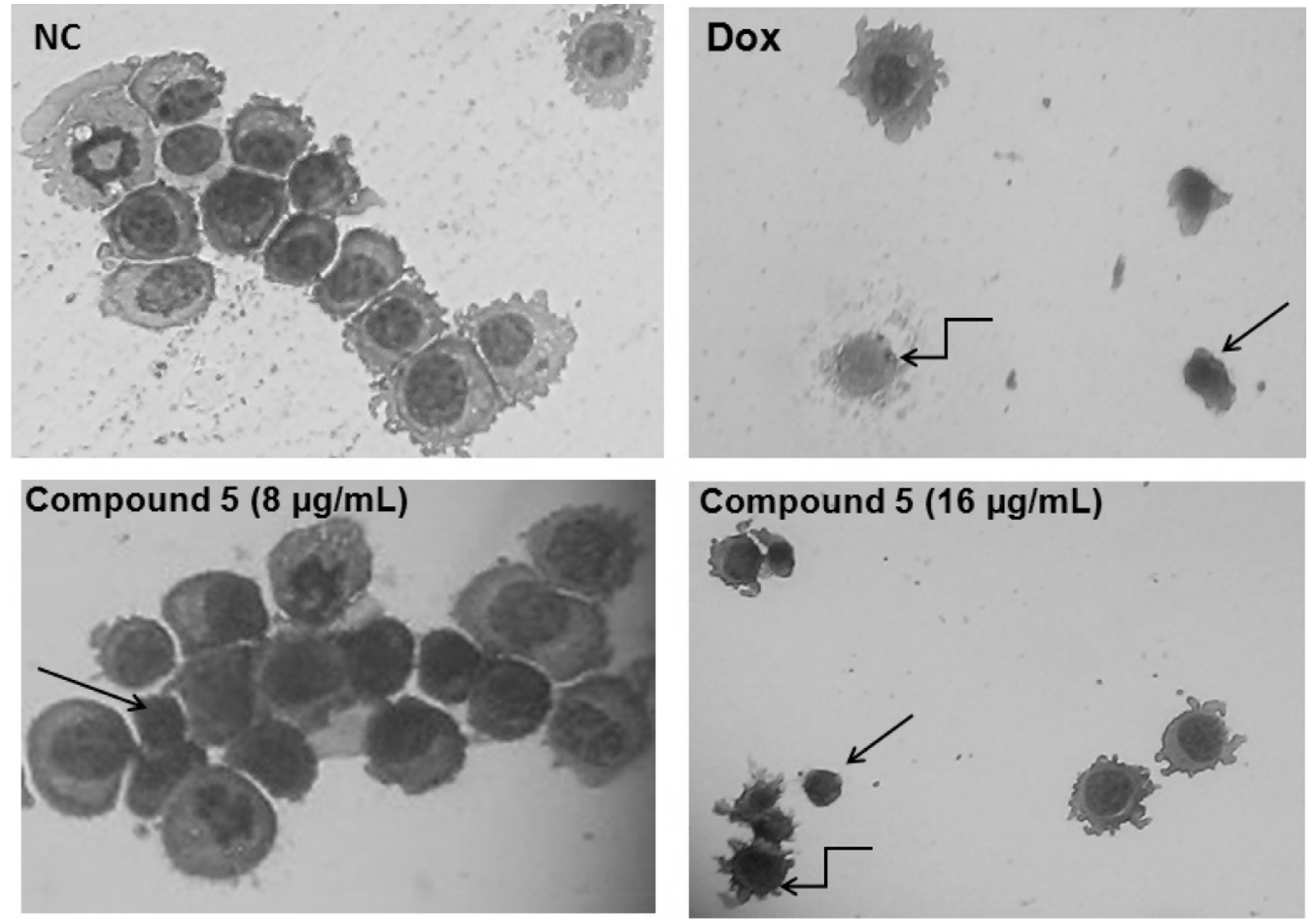

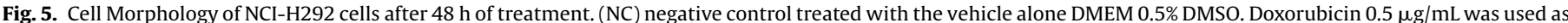

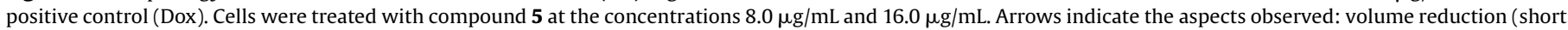
arrows) and cellular debris (curved arrows). Cells were stained with May - Grunwald - Giemsa and visualized by light microscopy with $400 \times$ magnification. 

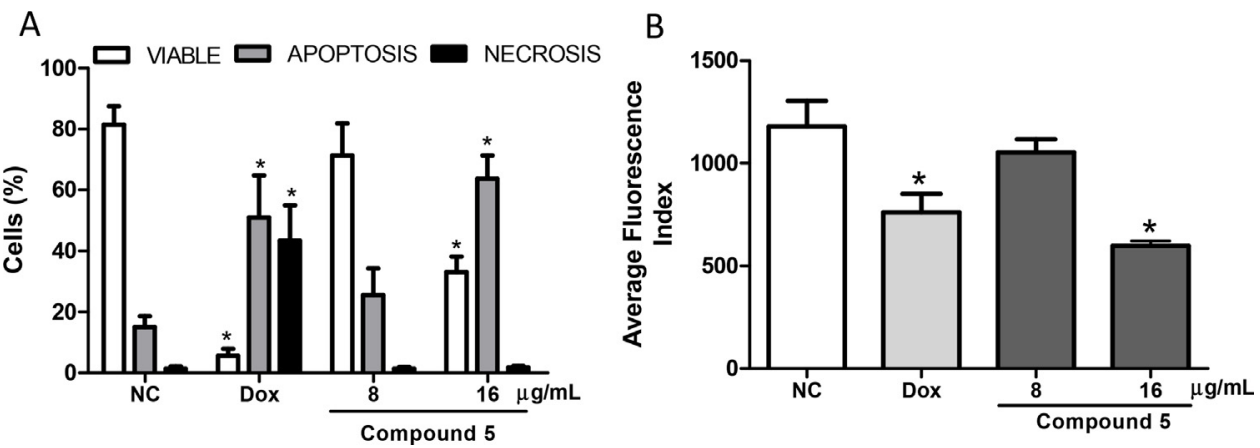

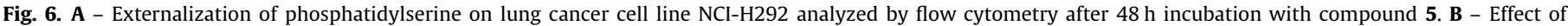

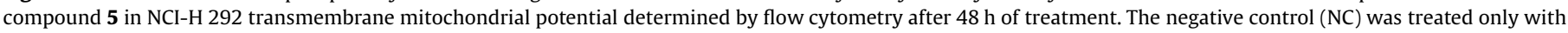

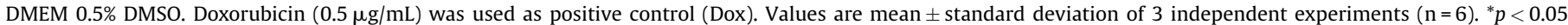
compared to negative control by ANOVA followed by Dunnett's test.

significant increase $(p<0.05)$ in mitochondrial depolarization was observed (Figs. 6 and 7). Doxorubicin $(0.5 \mu \mathrm{g} / \mathrm{mL})$ was also able to promote significant mitochondrial depolarization at the concentration tested $(p<0.05)$ (Fig. 6).

\section{Analysis of cell cycle and DNA fragmentation}

$\mathrm{NCI}-\mathrm{H} 292$ cells were treated with compound 5 for $48 \mathrm{~h}$ (Fig. 8) and $72 \mathrm{~h}$ (Fig. 9) at $\mathrm{IC}_{50}$ and $2 \times \mathrm{IC}_{50}$ and DNA content was quantified by flow cytometry. After $48 \mathrm{~h}$ of treatment, an increase on subdiploid DNA was observed when cells were treated with compound 5 at $16 \mu \mathrm{g} / \mathrm{mL}$ ( $16.12 \%$ after $48 \mathrm{~h}$ ) compared to negative control $(2.4 \%$ after $48 \mathrm{~h})(p<0.05)$. After $48 \mathrm{~h}$ there were no significant differences at cells cycle phases (G0/G1, S and G2/M) between treated and control cells (Fig. 8). After $72 \mathrm{~h}$ of treatment compound 5 at $1.26 \mu \mathrm{g} / \mathrm{mL}$ caused an increase of cells on G0/G1 $(59.8 \%$ after $72 \mathrm{~h})$ vs. negative control ( $41.3 \%$ after $72 \mathrm{~h})(p<0.05)$. When cells were treated with $2.52 \mu \mathrm{g} / \mathrm{mL}$ of compound 5 during $72 \mathrm{~h}$, an increase on subdiploid DNA (27.4\% after $72 \mathrm{~h}$ ) was observed (negative control $3.79 \%$ after $72 \mathrm{~h})(p<0.05)$.

\section{Genotoxicity assessment in PBMC and NCI-H292}

The in vitro genotoxic activity on both PBMC and lung cancer cell line NCI-H292 was assessed after $48 \mathrm{~h}$ by the Comet assay. To analyze the extent of damage to DNA molecules, data were expressed as damage index (ID) ranging from 0 (no damage) to 400 (maximum damage) (Fig. 10). No DNA damage was detected on PBMC after $48 \mathrm{~h}$ of treatment at any tested concentration of Compound $5(2.52 \mu \mathrm{g} / \mathrm{mL}$ e $5.0 \mu \mathrm{g} / \mathrm{mL})$ compared to the negative control; Conversely, Doxorubicin $(0.5 \mu \mathrm{g} / \mathrm{mL})$ caused significant DNA damage. For lung cancer cell line NCI-H292, compound 5 $(1.26 \mu \mathrm{g} / \mathrm{mL}$ e $2.52 \mu \mathrm{g} / \mathrm{mL})$ caused an increase on damage index of DNA at both tested concentrations $(1.26 \mu \mathrm{g} / \mathrm{mLe} 2.52 \mu \mathrm{g} / \mathrm{mL})$. Doxorubicin also increased DNA damage on NCI-H292.

\section{Discussion}

Recently, compounds 2, 3, 4 and 5 were synthesized in satisfactory yields and tested against pteridine reductase 1 (PTR1), a promising enzyme as target for the development of antileishmanial drugs. Compound 3, the first non-competitive inhibitor of PTR1, presented a two-digit micromolar potency (less than $50 \mathrm{uM}$ ) in comparison with compounds 2, 4 and 5 [9]. Nonetheless, cytotoxic and genotoxic potentialities on neoplastic or normal cells have not been described yet.
Compounds 2 to 5 were screened against six tumor cell lines (HEP-2, HL-60, HT-29, K562, MCF-7 and NCI-H292) and 5 presented lowest $\mathrm{IC}_{50}$ values. The most sensitive cell line treated with compound 5 was NCI-H292 ( IC $_{50}$ value of $1.26 \mu \mathrm{g} /$ $\mathrm{mL}$ ). The presence of an electron releasing substituent methoxy group increased the activity of compound 5, while in compound 2 the presence of two strong electron withdrawing atoms (bromine and fluorine) reduced the cytotoxic activity. Previously, some studies have reported in vitro cytotoxic activities of thiazolidine-2,4-dione derivatives upon tumor lines of different histological types $[18,28,29]$. Amongst ten compounds synthesized, (2-[4-[(2,4-Dioxothiazolidin-5-ylidene) methyl] phenoxy]$\mathrm{N}$-[3-(trifluromethyl) phenyl] acetamide) showed potent cytotoxicity against five of the seven cell lines tested (breast cancer MCF-7, prostate cancer $\mathrm{PC} 3$, nasopharyngeal $\mathrm{KB}$, cancer oral cancer GURAV and leukemia K562) [18]. Another group of derivatives where the substitution reaction occurs at the third position of the 2,4- thiazolidinedione ring presented two active compounds against MCF-7 cell line [28]. Recently, two series of thiazolidinediones were synthesized and their cytotoxicity evaluated in prostate adenocarcinoma PC-3, breast adenocarcinoma MDA-MB-231, and fibrosarcoma HT-1080 cancer cell lines. Most of the compounds synthesized were active against at least one cell line, being 5-\{4-[(3-(4-Chlorophenyl)-3,4-dihydro-4oxoquinazolin-2-yl)methoxy]benzylidene\}thiazolidine-2,4-dione the most active compound. Moreover, mechanistic investigation revealed pro-apoptotic activity of the most cytotoxic compound [29].

In order to verify whether the cytotoxicity is related to direct cell membrane damage, the compounds were incubated with human erythrocytes. None of the compounds induced lysis of human erythrocytes $\left(\mathrm{EC}_{50}>125 \mu \mathrm{g} / \mathrm{mL}\right.$ ). Probably, the cytotoxicity of compound 5 toward tumor cells occurs by a more specific mechanism other than an immediate and direct disruption of cell membrane. In fact, treatment of $\mathrm{NCI}-\mathrm{H} 292$ cells for a brief period such as $24 \mathrm{~h}$ with compound 5 did not reduce cell growth. Only after $48 \mathrm{~h}$ of treatment, a significant cytotoxicity on $\mathrm{NCI}-\mathrm{H} 292$ was observed with maximum effect achieved after $72 \mathrm{~h}$. Lung cancer is currently the leading cause of cancer death worldwide and for most patients with this disease current treatments do not promote cure [3,30]. Additionally, cytotoxic action on normal cells (peripheral blood mononuclear cells) was not observed with compounds 2 to 5 $\left(\mathrm{IC}_{50}>25 \mu \mathrm{g} / \mathrm{mL}\right.$ ). Compound 5 demonstrated antiproliferative selectivity to lung cancer cells, since the tumor cells were affected by the treatment but not normal cells.

Morphological and biochemical patterns in NCI-H292 human lung cancer cells incubated with compound 5 were investigated. 

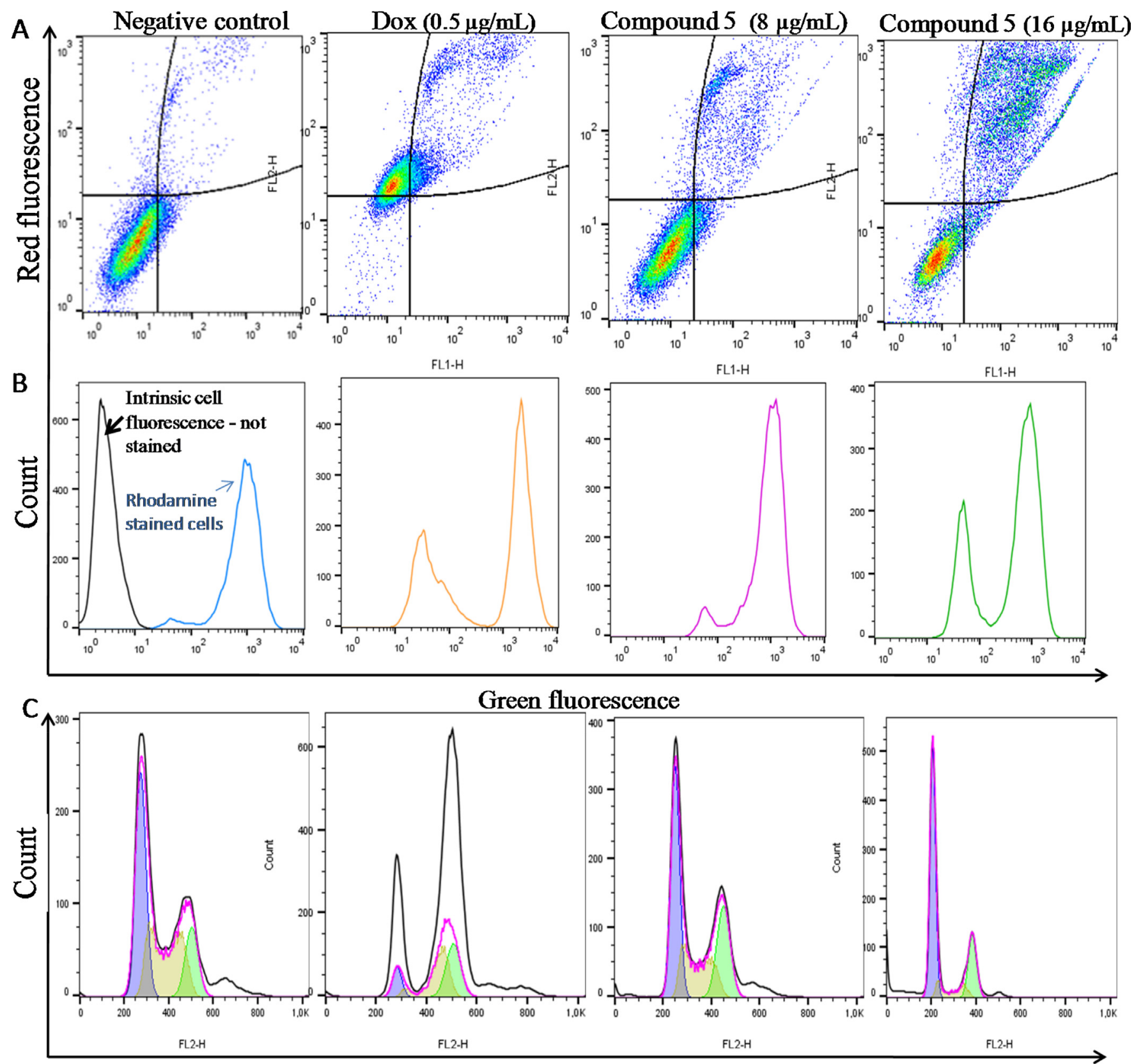

Red fluorescence

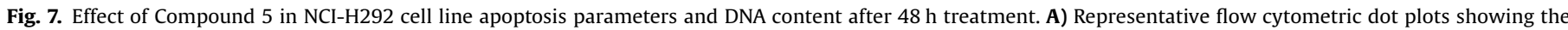

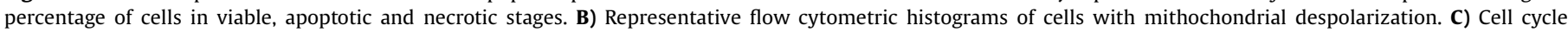
histograms. Dox: doxorubicin.

$\mathrm{NCI}-\mathrm{H} 292$ treated cells exhibited cell volume reduction and DNA fragmentation ( 8 and $16 \mu \mathrm{g} / \mathrm{mL}$ ), suggesting activation of apoptotic events. The process of cell death by apoptosis has some characteristics such as cell volume reduction, chromatin condensation, and nuclear fragmentation without extravasation of the cellular content [31]. So, unlike what happens in necrosis, no inflammatory process occurs [32]. Mitochondrial membrane depolarization and loss of plasma membrane phospholipid asymmetry also occur during the apoptosis process [33].

To confirm if morphological alterations in NCI-H292 treated cells were consistent with apoptosis, phosphatidylserine (PS) externalization was evaluated. An increase on NCI-H292 apoptosis was observed after $48 \mathrm{~h}$ of treatment with compound 5 and such findings were accompanied by mitochondrial depolarization and
DNA fragmentation $(16 \mu \mathrm{g} / \mathrm{mL})$. After $72 \mathrm{~h}$ of incubation, compound 5 caused DNA fragmentation in NCI-H292 cells at 6 -fold lower concentration $(2.5 \mu \mathrm{g} / \mathrm{mL})$ than that used for $48 \mathrm{~h}$ analyses and cell cycle arrest at $\mathrm{G0} / \mathrm{G} 1$ at $1.26 \mu \mathrm{g} / \mathrm{mL}$. A report has shown that hybrid molecules containing 5-benzilidene thiazolidine-2, 4-dione induced apoptosis on leukemia cells by activation of the extrinsic and the intrinsic pathways of cell death [14]. Pioglitazone (PGZ), a thiazolidinedione compound, induced growth inhibition and apoptosis of human B lymphocytic leukemia (SD1 cells). Treatment of these cells with the PPAR $\gamma$ ligand pioglitazone resulted in growth inhibition in a dose-dependent manner which was associated with a G1 to $S$ cell cycle arrest after 3 days of treatment. After 4 days of treatment PGZ caused significant apoptosis in lymphocytic leukemic cell lines [34]. TZD18, Another 


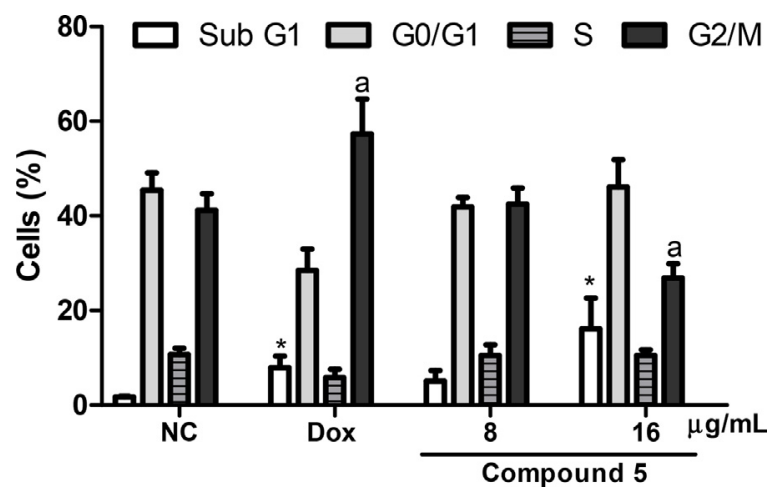

Fig. 8. The effect of compound 5 at $\mathrm{IC}_{50}$ and $2 \times \mathrm{IC}_{50}$ concentrations on the cell cycle of $\mathrm{NCI}-\mathrm{H} 292$ was determined by flow cytometry after $48 \mathrm{~h}$ of incubation. The negative control (NC) was treated only with DMEM 0.5\% DMSO. Doxorubicin $(0.5 \mu \mathrm{g} / \mathrm{mL}$ ) was used as positive control (Dox). Values are mean \pm standard deviation of 3 independent experiments $(n=6) .{ }^{*} p<0.05$ when Sub G1 was compared to negative and ${ }^{\mathrm{a}} p<0.05$ when $\mathrm{G} 2 / \mathrm{M}$ was compared to negative control by ANOVA followed by Dunnett's test.

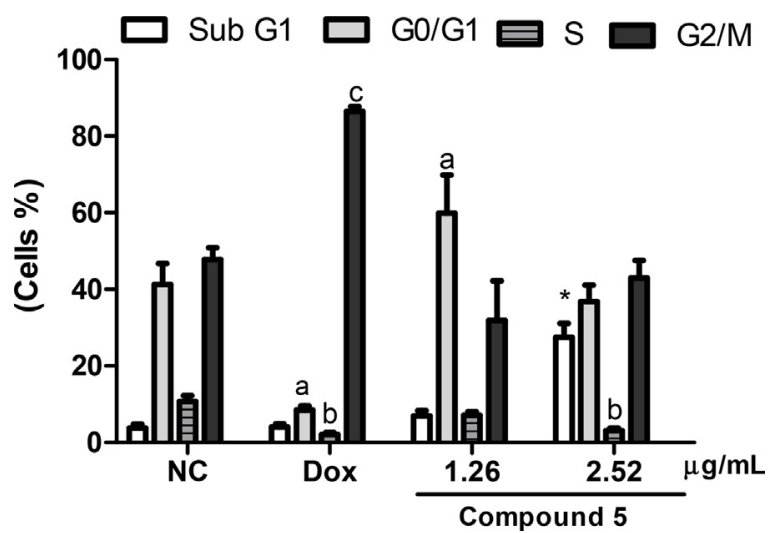

Fig. 9. The effect of compound 5 at $\mathrm{IC}_{50}$ and $2 \times \mathrm{IC}_{50}$ concentrations on the cell cycle of NCI-H292 determined by flow cytometry after $72 \mathrm{~h}$ of incubation. The negative control (NC) was treated only with DMEM 0.5\% DMSO. Doxorubicin $(0.5 \mu \mathrm{g} / \mathrm{mL})$ was used as positive control (Dox). Values are mean \pm standard deviation of 3 independent experiments $(n=6)$. ${ }^{a} p<0.05$ when G0/G1 was compared to negative control, ${ }^{\mathrm{b}} p<0.05$ when $\mathrm{S}$ phase was compared to negative control, ${ }^{\mathrm{c}} p<0.05$ when G2/M was compared to negative control, ${ }^{*} p<0.05$ when Sub G1 was compared to negative control. All of them were compared by ANOVA followed by Dunnett's test.
PPAR $\alpha$ and PPAR $\gamma$ agonist structurally related to the thiazolidinedione, induced $\mathrm{G} 1$ cell cycle arrest in $\mathrm{Ph}+$ lymphocytic leukemia cell line at $10 \mathrm{uM}$ and at higher concentration $(20 \mu \mathrm{M})$ induced apoptosis in a time-dependent fashion [35]. Thus, G1 arrest may represent one of the underlying mechanisms for subsequent cell apoptosis.

Thiazolidine-2,4-dione (TZDs) were evaluated regarding the expression of proteins that control the transition from the $\mathrm{G} 1$ to $\mathrm{S}$ cell cycle's phase in human prostate cancer cell lines [36]. Inhibitory concentrations of TZDs rosiglitazone and ciglitazone induced expression of p21 (Inhibitor of cyclin-dependent kinase) and decrease of cyclin D1 levels in PC-3 cells. Cell cycle arrest occurred due to the decrease in the level of cyclin proteins that regulate cell cycle progression [36].

The genotoxicity of compound 5 was accessed by alkaline comet assay. This technique allows quantitative evaluation of recent damage to DNA by single and double breaks [37] and has advantages over others DNA damage methods such as the micronucleus test because of its high sensitivity and early detection of DNA injury. Compound 5 did not cause genotoxicity in PBMC even for a prolonged period of treatment with $5 \mu \mathrm{g} / \mathrm{mL}$ ( $48 \mathrm{~h}$ ), but $\mathrm{NCl}-\mathrm{H} 292$ cells presented significant DNA damage at 4-fold lower concentrations than that used for normal cells $(1.25 \mu \mathrm{g} / \mathrm{mL})$. Doxorubicin $(0.5 \mu \mathrm{g} \mathrm{mL})$ also produced DNA damage in normal cells. DNA damage induced by compound 5 in NCI-H292 initiated with low concentration as detected by the comet assay and became more extensive with higher concentrations of compound 5, as detailed by flow cytometry assay. Although 5-benzylidene-thiazolidine-2,4-dione derivatives have been reported in a large number of biological activities, there are still a few studies that investigate possible genotoxic effects in normal lines. Recently, some thiazacridine derivatives (ATZD), a new class of cytotoxic agents combining one acridine nucleus with thiazolidine group, were described as non-genotoxic upon human lymphocytes [38]. Progress in the treatment of locally stage III Non-Small Cell Lung Cancer has been achieved with two chemotherapy doublets in combination with thoracic radiotherapy: 1) full-dose cisplatin plus etoposide (PE) for two cycles; and 2) weekly low-dose paclitaxel plus carboplatin (PC). However, advanced lung cancer has been resistant to traditional chemotherapy [39]. This data reinforce the need for encouragement of smoking cessation as a preventive approach and the development of new chemotherapeutic agents to treat lung cancer. Hence, we have identified compound 5- (2-bromo-5-methoxybenzylidene) thiazolidine-2,4-dione as a selective cytotoxic and pro-apoptotic
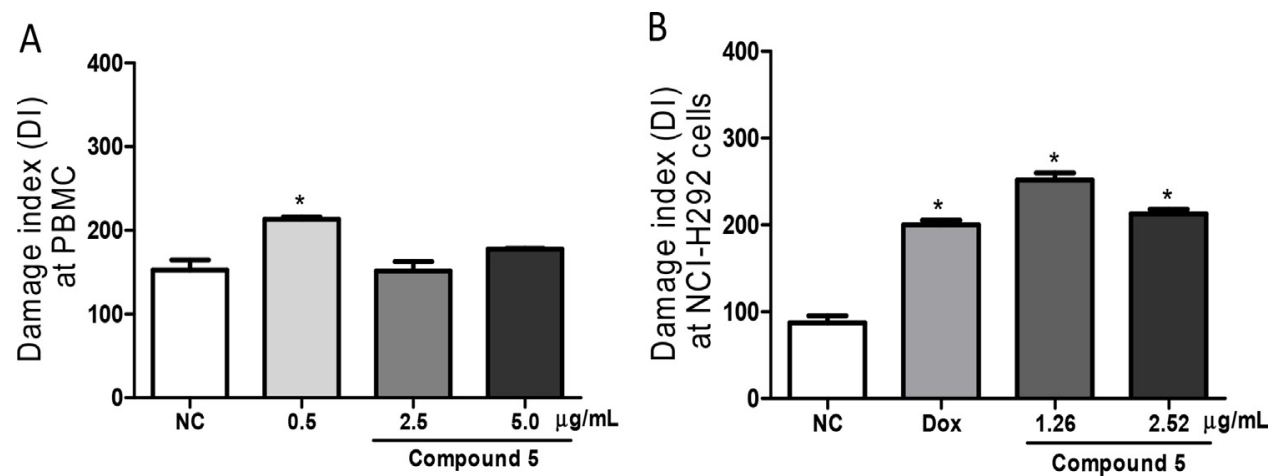

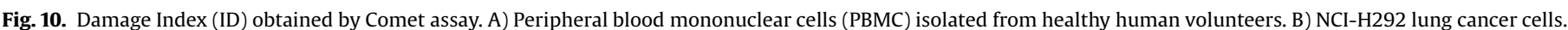

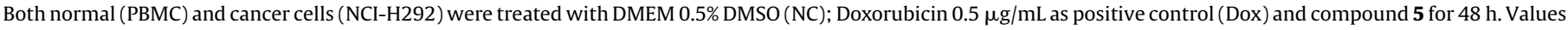

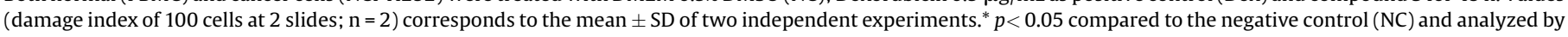
ANOVA followed by Dunnett's post test. 
agent against lung carcinoma cells. Furthermore, compound 5 did not show genotoxicity to normal cells.

\section{Conflict of interest}

None.

\section{Funding}

The authors thank Brazilian National Research Council (CNPq) and Research Foundation of Pernambuco State (FACEPE) for financial support.

\section{Acknowledgements}

We thank Maria Cicalese for English editing.

\section{Appendix A. Supplementary data}

Supplementary data associated with this article can be found, in the online version, at https://doi.org/10.1016/j.pharep.2017.11.008.

\section{References}

[1] Hanahan D., Weinberg RA. Hallmarks of cancer: the next generation. Cell 2011;144:646-74, doi:http://dx.doi.org/10.1016/j.cell.2011.02.013.

[2] Islami F, Torre LA, Jemal A. Global trends of lung cancer mortality and smoking prevalence. Transl Lung Cancer Res 2015;4:327-38, doi:http://dx.doi.org/ 10.3978/j.issn.2218-6751.2015.08.04.

[3] IARC-WHO, Stewart BW, Wild CP. World Cancer Report 2014. International Agency for Research on Cancer; 20149283204298.

[4] WHO. Cancer. WHO; 2017 http://www.who.int/mediacentre/factsheets/fs297/ en/ (Accessed 26 September 2017).

[5] Nazreen S, Alam MS, Hamid H, Yar MS, Dhulap A, Alam P, et al. Thiazolidine-2, 4-diones derivatives as PPAR- $\gamma$ agonists: synthesis, molecular docking, in vitro and in vivo antidiabetic activity with hepatotoxicity risk evaluation and effect on PPAR- $\gamma$ gene expression. Bioorg Med Chem Lett 2014;24:3034-42, doi: http://dx.doi.org/10.1016/j.bmcl.2014.05.034.

[6] Maggs DG, Buchanan TA, Burant CF, Cline G, Gumbiner B, Hsueh WA, et al. Metabolic effects of troglitazone monotherapy in type 2 diabetes mellitus A randomized, double-blind, placebo-controlled trial. Ann Intern Med $1998 ; 128: 176-85$

[7] da Silva IM, da Silva Filho J, Santiago PBG, da S, do Egito MS, de Souza CA, et al. Synthesis and antimicrobial activities of 5-Arylidene-thiazolidine-2,4-dione derivatives. Biomed Res Int 2014;2014:316082, doi:http://dx.doi.org/10.1155/ 2014/316082.

[8] Barros CD, Amato AA, de Oliveira TB, Iannini KBR, da Silva AL, da Silva TG, et al. Synthesis and anti-inflammatory activity of new arylidene-thiazolidine-2,4diones as PPAR $y$ ligands. Bioorg Med Chem 2010;18:3805-11, doi:http://dx. doi.org/10.1016/j.bmc.2010.04.045.

[9] Leite FHA, Santiago PBG, da S, Froes TQ da Silva Filho J, da Silva SG, et al. Structure-guided discovery of thiazolidine-2,4-dione derivatives as a novel class of Leishmania major pteridine reductase 1 inhibitors. Eur J Med Chem 2016;123:639-48, doi:http://dx.doi.org/10.1016/j.ejmech.2016.07.060.

[10] Mohanty S, Reddy GS, Karmakar AC. Synthesis of new 5-substitutedaminomethylene-thiazolidine-2,4-dione derivatives As potential antibacterial agents. JOAC 2014;3:82-90.

[11] Asati V, Mahapatra DK, Bharti S. Thiazolidine-2,4-diones as multi-targeted scaffold in medicinal chemistry: potential anticancer agents. Eur J Med Chem 2014;87:814-33, doi:http://dx.doi.org/10.1016/J.EJMECH.2014.10.025.

[12] Patil V, Tilekar K, Mehendale-Munj S, Mohan R, Ramaa CS. Synthesis and primary cytotoxicity evaluation of new 5-benzylidene-2, 4- thiazolidinedione derivatives. Eur J Med Chem 2010;45:4539-44, doi:http://dx.doi.org/10.1016/j. ejmech.2010.07.014.

[13] Jung K-Y, Samadani R, Chauhan J, Nevels K, Yap JL, Zhang J, et al. Structural modifications of (Z)-3-(2-aminoethyl)-5-(4-ethoxybenzylidene)thiazolidine2,4-dione that improve selectivity for inhibiting the proliferation of melanoma cells containing active ERK signaling. Org Biomol Chem 2013;11:3706, doi: http://dx.doi.org/10.1039/c3ob40199e.

[14] Romagnoli R, Baraldi PG, Salvador MK, Camacho ME, Balzarini J, Bermejo J, et al. Anticancer activity of novel hybrid molecules containing 5-benzylidene thiazolidine-2, 4-dione. Eur J Med Chem 2013;63:544-57, doi:http://dx.doi. org/10.1016/j.ejmech.2013.02.030.

[15] Blanquicett C, Roman J, Hart CM. Thiazolidinediones as anti-cancer agents. Cancer Ther 2008;6:25-34.
[16] Jain VS, Vora DK, Rama CS. Thiazolidine-2, 4-diones. progress towards multifarious applications. Bioorg Med Chem 2013;21:1599-620, doi:http://dx. doi.org/10.1016/j.bmc.2013.01.029.

[17] Divya GS, Mansoor KP, Rasheed SP, Kumar A. PPAR gamma agonists: an effective strategy for cancer treatment. JPSI 2013;2:1-3, doi:http://dx.doi.org/ $10.7897 / 2277-4572.02575$.

[18] Patil V, Tilekar K, Mehendale-Munj S, Mohan R, Ramaa CS. Synthesis and primary cytotoxicity evaluation of new 5-benzylidene-2, 4- thiazolidinedione derivatives. Eur J Med Chem 2010;45:4539-44, doi:http://dx.doi.org/10.1016/j. ejmech.2010.07.014.

[19] Laxmi SV, Anil P, Rajitha G, Rao AJ, Crooks PA, Rajitha B. Synthesis of thiazolidine-2, 4-dione derivatives: anticancer, antimicrobial and DNA cleavage studies. J Chem Biol 2016;9:97-106, doi:http://dx.doi.org/10.1007/ s12154-016-0154-8.

[20] Libermann D, Himbert J, Hengl L. Thiazolidinone, a starting point for a synthesis of thiopyruvic and thioglyoxilic substituted acids. Bull Soc Chim Fr 1948; 1120-4 in French.

[21] Albuquerque JFC, Azevedo CC, Galdino SL, Chantegrel J, Pitta IR, Luu-Duc C. Synthesis and structural study of 5-arylidene thiazolidine-2, 4-diones and 4thioimidazolidin-2-ones-3-substituted. Ann Pharm Fr 1995;53:209-14 in French.

[22] Mosmann T. Rapid colorimetric assay for cellular growth and survival: application to proliferation and cytotoxicity assays. J Immunol Methods 1983;65:55-63, doi:http://dx.doi.org/10.1016/0022-1759(83)90303-4.

[23] O'Brien J. Wilson I, Orton T, Pognan F. Investigation of the Alamar Blue (resazurin) fluorescent dye for the assessment of mammalian cell cytotoxicity. Eur J Biochem 2000;267:5421-6, doi:http://dx.doi.org/10.1046/j.14321327.2000.01606.x.

[24] Militão GCG, Dantas INF, Pessoa C, Falcão MJC, Silveira ER, Lima MAS, et al. Induction of apoptosis by pterocarpans from Platymiscium floribundum in $\mathrm{HL}-$ 60 human leukemia cells. Life Sci 2006;78:2409-17, doi:http://dx.doi.org/ 10.1016/j.lfs.2005.09.044.

[25] Ferreira PMP, Bezerra DP, Do Nascimento Silva J, Da Costa MP, De Oliveira Ferreira JR, Alencar NMN, et al. Preclinical anticancer effectiveness of a fraction from Casearia sylvestris and its component Casearin X: in vivo and ex vivo methods and microscopy examinations. J Ethnopharmacol 2016;186:270-9, doi:http://dx.doi.org/10.1016/j.jep.2016.04.011.

[26] Singh NP, McCoy MT, Tice RR, Schneider EL. A simple technique for quantitation of low levels of DNA damage in individual cells. Exp Cell Res 1988;175:184-91, doi:http://dx.doi.org/10.1016/0014-4827(88)90265-0.

[27] Collins AR. The comet assay for DNA damage and repair: principles, applications, and limitations. Mol Biotechnol 2004;26:249-61, doi:http:// dx.doi.org/10.1385/MB:26:3:249.

[28] Akshaya TT, Arunlal VB, Babu G, Biju CR. Synthesis, characterisation and. JDDT 2014;2:42-7.

[29] Metwally K, Pratsinis H, Kletsas D. Novel 2,4- thiazolidinediones: synthesis, in vitro cytotoxic activity, and mechanistic investigation. Eur J Med Chem 2017;133:340-50, doi:http://dx.doi.org/10.1016/j.ejmech.2017.03.052.

[30] Islami F, Torre LA, Jemal A. Global trends of lung cancer mortality and smoking prevalence. Transl Lung Cancer Res 2015;4:327-38, doi:http://dx.doi.org/ 10.3978/j.issn.2218-6751.2015.08.04.

[31] Kerr JF, Wyllie AH, Currie AR. Apoptosis: a basic biological phenomenon with wide-ranging implications in tissue kinetics. Br J Cancer 1972;26:239-57.

[32] Fadeel B, Orrenius S. Apoptosis A basic biological phenomenon with wideranging implications in human disease. J Intern Med 2005;258:479-517, doi: http://dx.doi.org/10.1111/j.1365-2796.2005.01570.x.

[33] Leist M, Jäättelä M. Four deaths and a funeral: from caspases to alternative mechanisms. Nat Rev Mol Cell Biol 2001;2:589-98, doi:http://dx.doi.org/ $10.1038 / 35085008$.

[34] Zang C, Liu H, Posch MG, Waechter M, Facklam M, Fenner MH, et al. Peroxisome proliferator-activated receptor $\gamma$ ligands induce growth inhibition and apoptosis of human B lymphocytic leukemia. Leuk Res 2004;28:387-97, doi: http://dx.doi.org/10.1016/j.leukres.2003.07.005.

[35] Liu H, Zang C, Fenner MH, Liu D, Possinger K, Koeffler HP, et al. Growth inhibition and apoptosis in human Philadelphia chromosome-positive lymphoblastic leukemia cell lines by treatment with the dual PPAR alpha/ gamma ligand TZD18. Blood 2006;107:3683-92, doi:http://dx.doi.org/ 10.1182/blood-2005-05-2103.Supported.

[36] Lyles BE, Akinyeke TO, Moss PE, Stewart LV. Thiazolidinediones regulate expression of cell cycle proteins in human prostate cancer cells via PPAR $\gamma$ dependent and PPAR $\gamma$-independent pathways. ABBV Cell Cycle 2009;8:26877, doi:http://dx.doi.org/10.4161/cc.8.2.7584.

[37] Araldi R, Melo TC, Mendes TB, Sá Júnior P, Nozima BH, Ito ET, et al. Using the comet and micronucleus assays for genotoxicity studies: a review. Biomed Pharmacother 2015;72:74-82.

[38] Barros FWA, Bezerra DP, Ferreira PMP, Cavalcanti BC, Silva TG, Pitta MGR, et al. Inhibition of DNA topoisomerase I activity and induction of apoptosis by thiazacridine derivatives. Toxicol Appl Pharmacol 2013;268:37-46, doi:http:// dx.doi.org/10.1016/j.taap.2013.01.010.

[39] Wakelee H, Kelly K, Edelman MJ. 50 Years of progress in the systemic therapy of non-small cell lung cancer. American Society of Clinical Oncology Educational Book/ASCO American Society of Clinical Oncology Meeting. . p. 177-89, doi:http://dx.doi.org/10.14694/EdBook_AM.2014.34.177. 